Е. Д. Скаковский ${ }^{1}$ Л. Ю. Тычинская ${ }^{1}$, С. В. Матвейчук', А. Ю. Клюев ${ }^{2}$, Е. И. Гапанькова ${ }^{1}$, И. А. Латышевич ${ }^{1}$

${ }^{1}$ Институт физико-органической химии Национальной академии наук Беларуси

${ }^{2}$ Белорусский государственный технологический университет

\title{
ЯМР-АНАЛИЗ ТЕРМИЧЕСКИХ РЕАКЦИЙ СМОЛЯНЫХ КИСЛОТ КАНИФОЛИ
}

Проведен сравнительный ${ }^{1} \mathrm{H}$ и ${ }^{13} \mathrm{C}$ ЯМР-анализ термических реакций двух образцов канифоли и выделенной из нее абиетиновой кислоты при температурах 190 и $220^{\circ} \mathrm{C}$ с открытым доступом воздуха. Канифоль произведена на ОАО «Лесохимик» (Борисов) в 2006 и 2018 гг. В исходных образцах присутствовали 7 смоляных кислот: абиетиновая, дегидроабиетиновая, изопимаровая, неоабиетиновая, палюстровая, пимаровая и сандаракопимаровая. В выделенной абиетиновой кислоте $(82,9 \%)$ в качестве примеси присутствовали дегидроабиетиновая, изопимаровая, неоабиетиновая и палюстровая кислоты.

Было установлено, что нагревание канифоли при $190^{\circ} \mathrm{C}$ приводит к обратимой изомеризации смоляных кислот абиетанового скелета с установлением нового соотношения их содержания. Содержание кислот с пимарановым скелетом практически не изменяется. Показано, что окисление и деструкция в этих условиях незначительны. Нагревание смеси, обогащенной абиетиновой кислотой, способствует заметному расходованию ее с образованием дополнительного количества присутствующих в смеси кислот.

Термолиз канифоли и выделенной абиетиновой кислоты при $220^{\circ} \mathrm{C}$ изменяет динамику реакций, приводя к заметной деструкции компонентов смеси, а эффективное взаимодействие с молекулярным кислородом дает не только дегидроабиетиновую кислоту, но и ряд новых кислот и кетонов.

Ключевые слова: смоляные кислоты, канифоль, нагревание, состав, спектры ЯМР.

Для цитирования: Скаковский Е. Д., Тычинская Л. Ю., Матвейчук С. В., Клюев А. Ю., Гапанькова Е. И., Латышевич И. А. ЯМР-анализ термических реакций смоляных кислот канифоли // Труды БГТУ. Сер. 2, Химические технологии, биотехнологии, геоэкология. 2021. № 1 (241). С. 74-81.

\section{E. D. Skakovskiii ${ }^{1}$ L. Yu. Tychinskaya ${ }^{1}$, S. V. Matveichuk ${ }^{1}$,} A. Yu. Klyuev ${ }^{2}$, A. I. Hapankova ${ }^{1}$, I. A. Latyshevich ${ }^{1}$

${ }^{1}$ Institute of Physical and Organic Chemistry of the National Academy of Sciences of Belarus ${ }^{2}$ Belarusian State Technological University

\section{NMR ANALYSIS OF THERMAL REACTIONS OF RESIN ACID OF ROSIN}

A comparative ${ }^{1} \mathrm{H}$ and ${ }^{13} \mathrm{C}$ NMR analysis of the thermal reactions of two samples of rosin and the abietic acid isolated from it at temperatures of 190 and $220^{\circ} \mathrm{C}$ with open air was carried out. Rosin was produced at JSC "Lesokhimik" (Borisov, Belarus) in 2006 and 2018. Seven resin acids were present in the initial samples: abietic, dehydroabietic, isopimaric, neo-abietic, palusturic, pimaric and sandaracopymaric. We found an additional four acids in abietic acid (82.9\%), which was isolated: dehydroabietic, isopimaric, neo-abietic, and palusturic.

It was found that heating rosin at $190^{\circ} \mathrm{C}$ leads to the reversible isomerization of resin acids of the abietanic skeleton with the establishment of a new ratio of their content. The content of pimaranic type acids remains practically unchanged. It is shown that oxidation and destruction under these conditions are insignificant. Heating a mixture with a high content of abietic acid leads to a noticeable expenditure of it with the formation of an additional amount of acids present in the mixture.

Thermolysis of rosin and isolated abietic acid at $220^{\circ} \mathrm{C}$ changes the dynamics of the reactions, that leads to a noticeable destruction of the components of the mixture. The effective interaction with molecular oxygen leads to the formation of dehydroabietic acid, some new acids and ketones.

Key words: resin acids, rosin, heating, composition, NMR spectrum.

For citation: Skakovskii E. D., Tychinskaya L. Yu., Matveichuk S. V., Klyuev A. Yu., Hapankova A. I., Latyshevich I. A. NMR analysis of thermal reactions of resin acid of rosin. Proceedings of BSTU, issue 2, Chemical Engineering, Biotechnologies, Geoecology, 2021, no. 1 (241), pp. 74-81 (In Russian).

Введение. Перспективной сырьевой отраслью белорусской экономики является лесное хозяйство. Важное место среди лесохимических производств занимает канифольно-терпентинное производство, основным сырьем которого служит живица, получаемая при подсочке сосен. 
В Республике Беларусь наиболее распространенной является сосна обыкновенная (Pinus sylvestris $\mathrm{L}$.).

B состав живицы данного вида сосны входят моно-, сескви- и дитерпены, причем главными компонентами являются смоляные кислоты (СК). Четыре СК имеют абиетановый скелет: абиетиновая, неоабиетиновая, левопимаровая и палюстровая, а три - пимарановый скелет: пимаровая, изопимаровая и сандаракопимаровая. Кроме того, в живице присутствует ароматическая дегидроабиетиновая СК [1]. Отгонкой терпенов из очищенной и обезвоженной живицы получают жидкий дистиллят (скипидар) и твердый осадок (канифоль), в котором содержатся преимущественно семь СК. Левопимаровая кислота из-за ее относительной неустойчивости преобразуется в три другие СК с абиетановым скелетом, а также дегидроабиетиновую [2].

Канифоль потребляют в большом количестве в бумажной, мыловаренной, химической, лакокрасочной, фармацевтической и других отраслях промышленности.

Практически во всех случаях применяется не сама канифоль, а ее производные, полученные в реакциях с другими соединениями при повышенной температуре. Отсюда понятен интерес к возможным превращениям СК канифоли в процессе термических реакций. В ранних работах [3, 4] было показано, что многие СК при нагревании превращаются в абиетиновую кислоту, а нагревание при более высоких температурах приводит к реакциям дегидрогенизации, диспропорционирования, изомеризации, полимеризации и декарбоксилирования. Основные результаты были получены на основе анализа кислотных чисел и оптического вращения.

В работах $[5,6]$ достаточно подробно рассмотрена термическая изомеризация СК канифоли. Установлено, что термическая обработка живичной канифоли при $225-250^{\circ} \mathrm{C}$ способствует в основном процессу изомеризации палюстровой и неоабиетиновой кислот в абиетиновую, тогда как нагревание при $275-300^{\circ} \mathrm{C}$ сопровождается главным образом процессом диспропорционирования абиетиновой кислоты до дегидро-, дигидро- и тетрагидроабиетиновых кислот. Одновременно наблюдается декарбоксилирование СК, приводящее к понижению кислотного числа. Эти результаты были получены на основе химического титрования, а также при помощи УФ- и ИК-спектроскопии. Однако эти методы не позволяют наблюдать индивидуальные СК и их продукты и, соответственно, получить достоверные результаты.
Термическая деструкция канифоли была также изучена методом синхронного термического анализа, включающего дифференциальную сканирующую калориметрию и термогравиметрию, совмещенные с масс-спектрометрическим анализом продуктов газовыделения при нагревании до $600^{\circ} \mathrm{C}$ в атмосфере аргона [7]. Наблюдающиеся эндотермические эффекты связали с процессами размягчения, тепловой изомеризации и диспропорционирования абиетиновой кислоты в дегидро- и дигидроабиетиновые кислоты. Установлено, что нагревание выше $200^{\circ} \mathrm{C}$ приводит к деструкции канифоли предположительно с отщеплением боковых алкильных радикалов абиетиновой кислоты, а затем к элиминированию карбоксильной группы. Однако и в этом случае нельзя говорить о достоверных результатах.

При анализе СК канифоли хорошо зарекомендовал себя метод ЯМР ${ }^{1} \mathrm{H}$ и ${ }^{13} \mathrm{C}$, поскольку он позволяет идентифицировать не только СК, но также и монотерпены и другие соединения $[8,9]$.

Цель настоящей работы - ЯМР-анализ термических превращений СК канифоли, а также ее главного компонента - абиетиновой кислоты.

Основная часть. Исследовали образцы канифоли, произведенные ОАО «Лесохимик» (Борисов) в 2006 и 2018 гг. Образцы 2006 г. подвергали нагреванию в течение 15 ч при температуре $190^{\circ} \mathrm{C}$ (эксперимент проводили в 2007 г.), более поздние образцы в 2019 г. грели 3 ч при $220^{\circ} \mathrm{C}$. Через каждый час отбирали пробы для анализа состава. Исходные и подвергшиеся нагреванию образцы растворяли в $\mathrm{CDCl}_{3}$ и записывали спектры ${ }^{1} \mathrm{H}$ и ${ }^{13} \mathrm{C}$ ЯМР. Для спектральной идентификации соединений из канифоли были выделены СК по методике, предложенной в работе [10]. Из-за малого содержания нам не удалось выделить сандаракопимаровую кислоту, поэтому для нее использованы литературные данные [11].

Поскольку абиетиновая кислота является главным компонентом канифоли, были дополнительно исследованы термические превращения выделенной абиетиновой кислоты в аналогичных условиях. Большинство технологических процессов, связанных с нагреванием канифоли, проводится на воздухе, поэтому реакции осуществляли в открытых керамических тиглях. Нагревание образцов при $190^{\circ} \mathrm{C}$ проводили в сушильном шкафу, а при $220^{\circ} \mathrm{C}-$ в муфельной печи. После окончания термолиза определяли потерю веса образцов.

Спектры ЯМР исследуемых образцов канифоли и абиетиновой кислоты в $\mathrm{CDCl}_{3}$ зарегистрированы на спектрометре AVANCE-500 (Bruker) с рабочими частотами 500 и 125 МГц для ядер ${ }^{1} \mathrm{H}$ и ${ }^{13} \mathrm{C}$ соответственно при температуре 
293 К. В качестве внутреннего стандарта для ${ }^{1} \mathrm{H}$ спектров использовали сигнал $\mathrm{CHCl}_{3}$, присутствующего в виде примеси в растворителе ( $\delta=7,27$ м.д.), а для ${ }^{13} \mathrm{C}$ спектров - сигнал самого растворителя ( $\delta=77,7$ м.д.). Спектры записаны в количественном режиме. Все экспериментальные данные получены и обработаны с помощью пакета программ XWIN-NMR 3.5.

Гравиметрический анализ показал, что нагревание образцов при температуре $190^{\circ} \mathrm{C}$ приводит к незначительной потере веса $(\sim 1 \%$ в течение каждого часа). Нагревание при $220^{\circ} \mathrm{C}$ дает более существенные изменения веса $(\sim 5 \%)$ в течение 1 ч. После 3 ч нагревания в обоих случаях изменения становятся менее заметными.

На рис. 1 приведены спектры ЯМР растворов исходной канифоли, которую затем нагревали при $190^{\circ} \mathrm{C}$.

Спектры демонстрируют, что в образце присутствуют абиетиновая, дегидроабиетиновая, изопимаровая, неоабиетиновая, палюстровая, пимаровая и сандаракопимаровая кислоты. Отнесение их сигналов дано в работах $[8,11]$.

Содержание СК приведено в табл. 1.

Главными компонентами в исходной канифоли являются абиетиновая $(43,5 \%)$, палюстровая $(19,9 \%)$ и неоабиетиновая $(13,6 \%)$ кислоты. Нагревание приводит к изменению содержания СК. Так, возрастает количество абиетиновой и дегидроабиетиновой кислот и уменьшается неоабиетиновой и палюстровой. Необходимо отметить, что в начальный период (1 ч) изменения наиболее существенные, а затем уменьшаются, и после 3 ч нагревания содержание этих кислот не изменяется. СК, имеющие пимарановый скелет, в пределах ошибки измерения не изменяют своего содержания. Наглядно все изменения по количественному составу СК после нагревания канифоли при $190^{\circ} \mathrm{C}$ в течение 3 ч отражают спектры ЯМР (рис. 2).
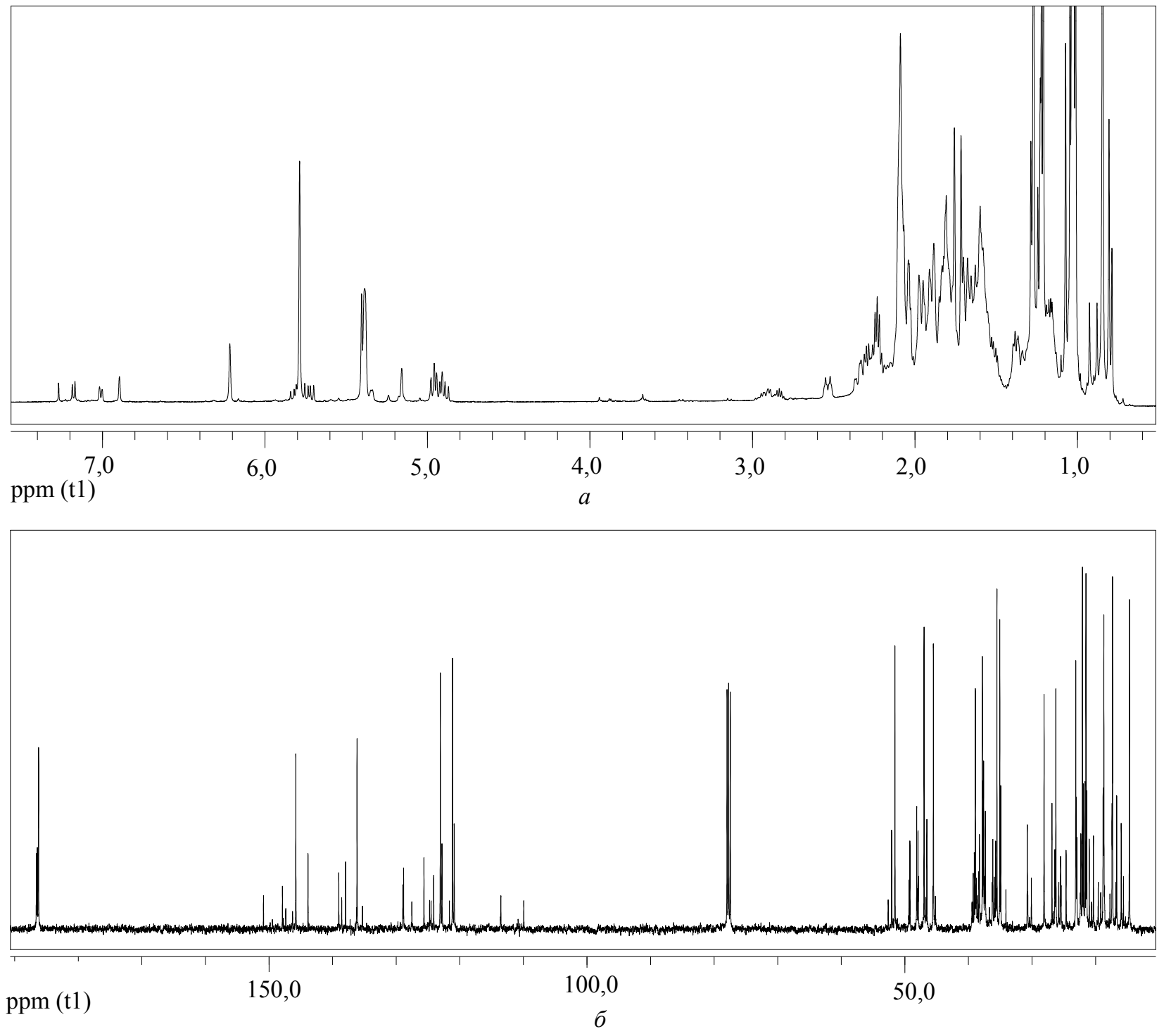

Рис. 1. Спектры ЯМР растворов исходной канифоли: $a-{ }^{1} \mathrm{H} ; \sigma-{ }^{13} \mathrm{C}$ 
Содержание смоляных кислот в нагретой канифоли, мол. \%

Таблица 1

\begin{tabular}{|c|l|c|c|c|c|c|c|c|c|}
\hline \multirow{2}{*}{ № п/п } & \multirow{3}{*}{ Смоляные кислоты } & \multicolumn{6}{|c|}{ Содержание смоляных кислот после нагревания канифоли при температуре } \\
\cline { 3 - 10 } & & \multicolumn{3}{|c|}{$190^{\circ} \mathrm{C}$} & \multicolumn{4}{|c|}{$220^{\circ} \mathrm{C}$} \\
\cline { 3 - 10 } & & 0 ч & 1 ч & 2 ч & 3 ч & 0 ч & 1 ч & 2 ч & 3 ч \\
\hline 1 & Абиетиновая & 43,5 & 55,9 & 59,2 & 59,6 & 30,5 & 50,3 & 38,4 & 34,8 \\
\hline 2 & Дегидроабиетиновая & 5,2 & 5,6 & 6,2 & 6,2 & 4,4 & 17,1 & 23,5 & 26,2 \\
\hline 3 & Изопимаровая & 6,3 & 6,3 & 6,2 & 6,2 & 7,6 & 10,2 & 9,8 & 8,8 \\
\hline 4 & Неоабиетиновая & 13,6 & 7,7 & 5,4 & 5,0 & 13,6 & 1,0 & 1,5 & 1,8 \\
\hline 5 & Палюстровая & 19,9 & 13,3 & 10,8 & 10,6 & 22,3 & 0,7 & 2,4 & 2,7 \\
\hline 6 & Пимаровая & 9,4 & 9,1 & 9,2 & 9,3 & 11,4 & 12,6 & 12,2 & 11,5 \\
\hline 7 & Сандаракопимаровая & 1,0 & 1,4 & 1,3 & 1,2 & 2,0 & 2,0 & 2,2 & 2,2 \\
\hline
\end{tabular}
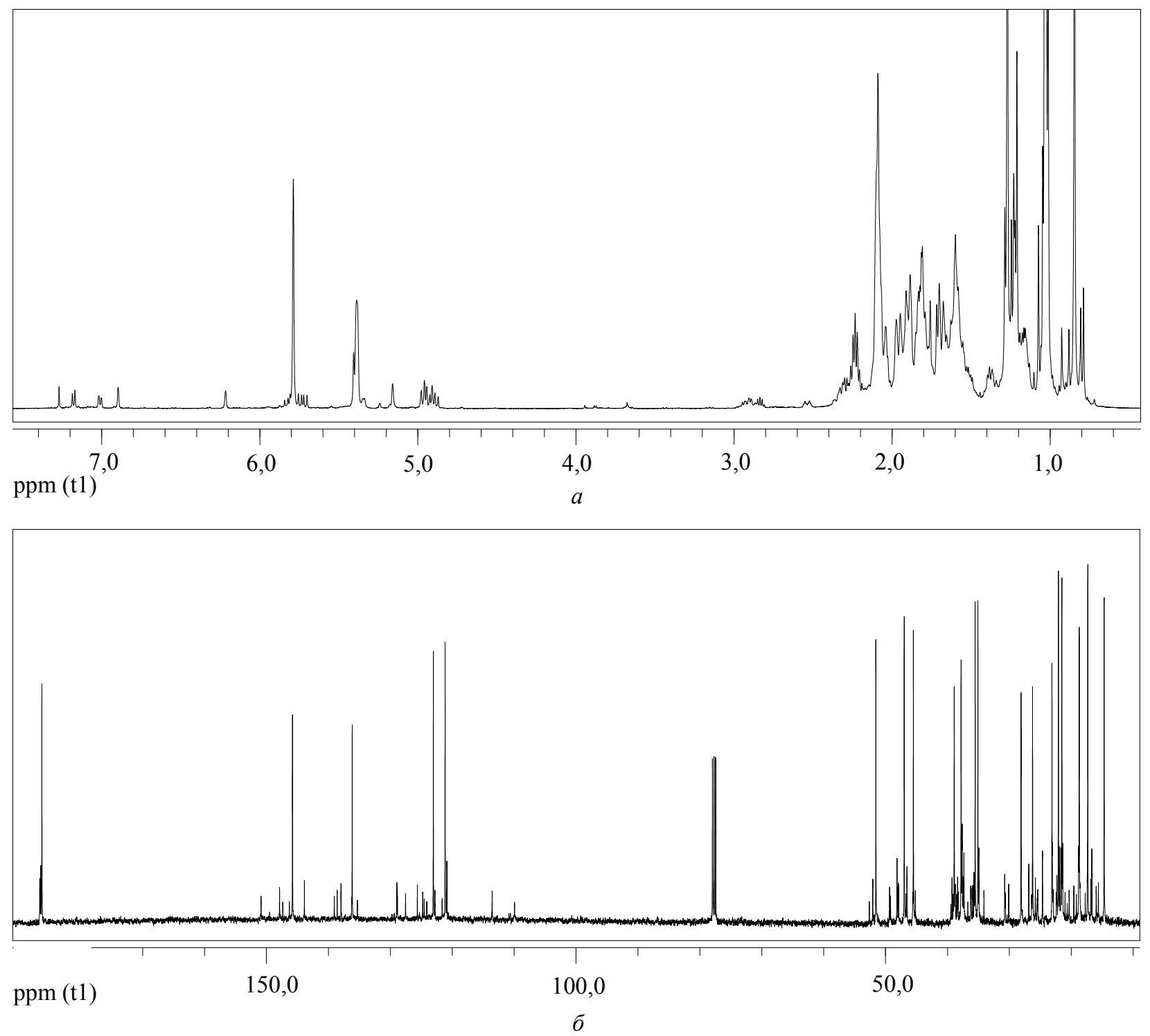

Рис. 2. Спектры ЯМР растворов канифоли после нагревания при $190^{\circ} \mathrm{C}$ в течение 3 ч:

$$
a-{ }^{1} \mathrm{H} ; \sigma-{ }^{13} \mathrm{C}
$$

Таким образом, нагревание канифоли при $190^{\circ} \mathrm{C}$ приводит практически только к изомеризации СК абиетанового скелета. Причем эти реакции обратимые, приводящие к установлению нового равновесного состава. Окисление и деструкция СК в этих условиях незначительны.
Ситуация принципиально изменяется, если нагревание канифоли осуществлять при температуре $220^{\circ} \mathrm{C}$. Содержание основных компонентов приведено в табл. 1, а спектры продуктов после нагревания в течение 3 ч представлены на рис. 3. 

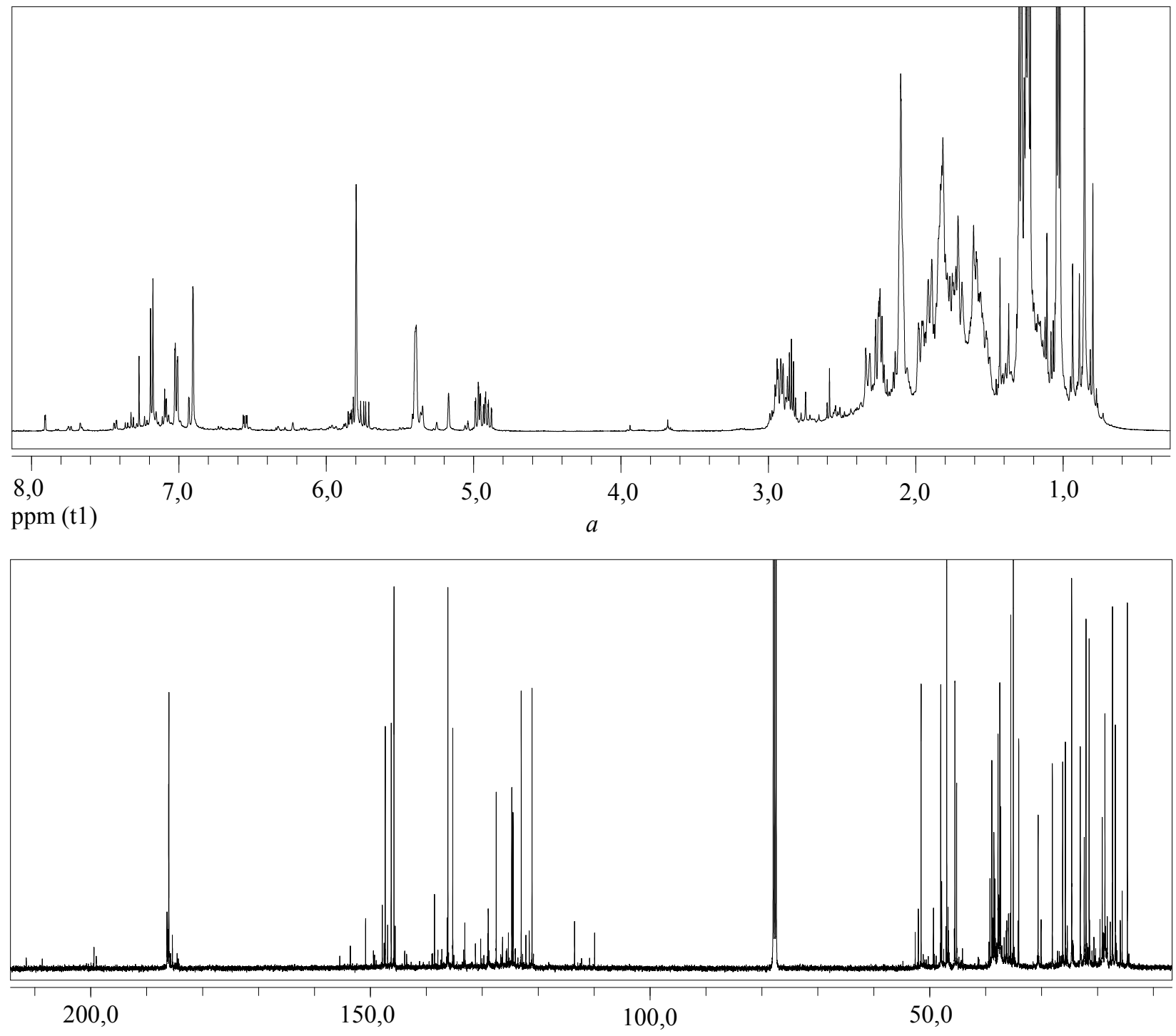

ppm (t1)

$\sigma$

Рис. 3. Спектры ЯМР растворов канифоли после нагревания при $220^{\circ} \mathrm{C}$ на протяжении 3 ч: $a-{ }^{1} \mathrm{H} ; \sigma-{ }^{13} \mathrm{C}$

Во-первых, заметно уменьшается содержание приведенных СК. Во-вторых, выделяется бурый дым при нагревании, что указывает на деструкцию канифоли. Об этом же свидетельствует динамика изменения содержания абиетиновой кислоты, которое сначала возрастает, а затем уменьшается.

В этих условиях реакции изомеризации протекают несколько по-другому, чем при $190^{\circ} \mathrm{C}$. Содержание неоабиетиновой и палюстровой кислот в начальный период резко уменьшается в реакционной смеси, а затем из-за обратимости реакций незначительно увеличивается.

Необходимо отметить, что нагревание канифоли при $220^{\circ} \mathrm{C}$ приводит к резкому увеличению содержания дегидроабиетиновой кислоты.

В работах [5-7] показано, что главным источником образования дегидроабиетиновой кислоты является реакция диспропорционирования, дающая одновременно и дигидроабиетиновую кислоту.
Однако мы не обнаружили ее в реакционной смеси. Логично предположить, что диспропорционирование абиетиновой кислоты происходит с молекулярным кислородом с образованием дегидроабиетиновой кислоты и воды.

Что касается СК с пимарановым скелетом, то при этой температуре так же, как и при $190^{\circ} \mathrm{C}$, их содержание практически не изменяется, указывая на их химическую инертность.

Интересные закономерности реакций СК можно наблюдать, анализируя слабопольную часть ${ }^{13} \mathrm{C}$ ЯМР-спектра канифоли, нагретой в течение 3 ч при $220^{\circ} \mathrm{C}$ (рис. 4).

Здесь, в отличие от исходной канифоли, где регистрировалось семь сигналов карбоксильных углеродных атомов, наблюдается уже двенадцать. Кроме того, в области от 198 до 212 м.д. проявляются не менее 4 сигналов карбонильных C-атомов, принадлежащих образовавшимся кетонам. 


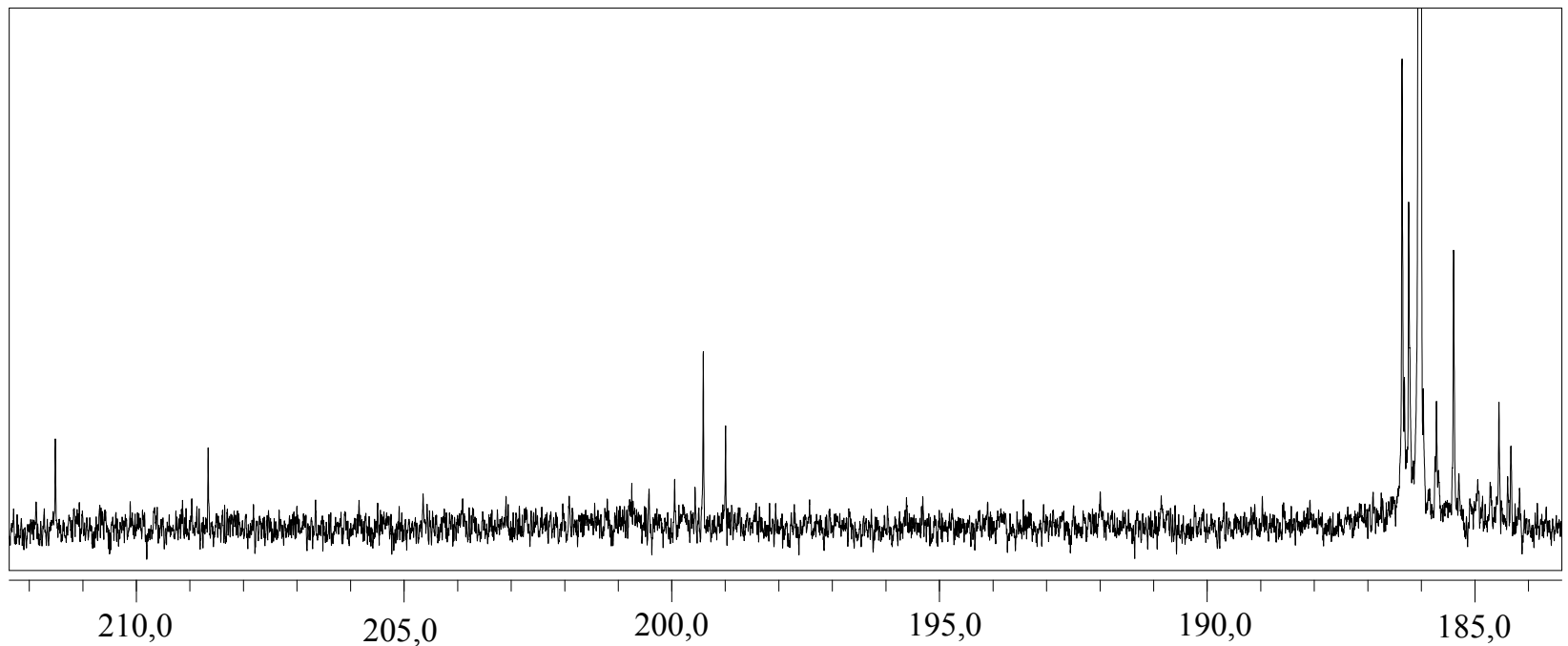

ppm (t1)

Рис. 4. Фрагмент ${ }^{13} \mathrm{C}$ ЯМР-спектра канифоли после нагревания при $220^{\circ} \mathrm{C}$ в течение 3 ч

Таким образом, можно утверждать, что в этом случае в реакции разложения СК с абиетановым скелетом активно участвует молекулярный кислород, который при диспропорционировании дает не только дегидроабиетиновую кислоту, но также ряд других, структуру которых необходимо устанавливать.

Кроме того, логично предположить, что СК при взаимодействии с кислородом дают различные пероксиды, разложение которых приводит к образованию наблюдаемых спектрально кетонов.

Дополнительно был исследован термолиз основного компонента канифоли - абиетиновой кислоты, полученной по методике [10]. Нам не удалось выделить индивидуальную кислоту, ее содержание в смеси составило 82,9\% (табл. 2).

Наряду с абиетиновой в смеси присутствовали дегидроабиетиновая, изопимаровая, неоабиетиновая и палюстровая СК. В отличие от канифоли, нагретой при $190^{\circ} \mathrm{C}$, в которой содержание абиетиновой кислоты возрастало за счет убыли неоабиетиновой и палюстровой, в аналогичных опытах с абиетиновой кислотой ее содержание заметно уменьшалось, а количество неоабиетиновой и палюстровой возрастало из-за обменных реакций. Наблюдался также рост дегидроабиетиновой кислоты, указывающий на активное участие молекулярного кислорода в реакции диспропорционирования даже в этих условиях.

Причины увеличения содержания изопимаровой кислоты неизвестны и требуют дополнительных исследований.

Нагревание абиетиновой кислоты при $220^{\circ} \mathrm{C}$ так же, как и при $190^{\circ} \mathrm{C}$, приводит к постепенному уменьшению ее количества в смеси, причем сначала быстро, а затем медленнее. Дегидроабиетиновая кислота ведет себя антибатно поведению абиетиновой, хорошо согласуясь с термолизом исходной канифоли и указывая, что главным путем ее образования является диспропорционирование СК с молекулярным кислородом. Концентрация неоабиетиновой и палюстровой кислот изменяется экстремально. Сначала она растет за счет изомеризации и обменных реакций, а затем падает из-за расходования их с образованием других соединений.

Необходимо отметить, что нагревание абиетиновой кислоты при $220^{\circ} \mathrm{C}$ дает такой же набор в спектрах сигналов новых карбоксильных и карбонильных групп образующихся различных соединений, как и для канифоли.

Таблица 2

Содержание смоляных кислот после нагревания абиетиновой кислоты, \%

\begin{tabular}{|c|c|c|c|c|c|c|c|c|}
\hline \multirow{3}{*}{ № п/п } & \multirow{3}{*}{ Смоляные кислоты } & \multicolumn{7}{|c|}{$\begin{array}{c}\text { Содержание смоляных кислот после нагревания абиетиновой кислоты } \\
\text { при температуре }\end{array}$} \\
\hline & & \multicolumn{4}{|c|}{$190^{\circ} \mathrm{C}$} & \multicolumn{3}{|c|}{$220^{\circ} \mathrm{C}$} \\
\hline & & $0 ч$ & 14 & $2 ч$ & 34 & $1 \mathrm{Y}$ & 24 & 34 \\
\hline 1 & Абиетиновая & 82,9 & 67,1 & 58,3 & 49,9 & 68,2 & 54,7 & 52,9 \\
\hline 2 & Дегидроабиетиновая & 5,6 & 13,4 & 18,1 & 19,4 & 10,7 & 18,3 & 20,3 \\
\hline 3 & Изопимаровая & 4,8 & 7,0 & 7,4 & 8,0 & 8,0 & 6,5 & 6,9 \\
\hline 4 & Неоабиетиновая & 2,8 & 2,0 & 2,4 & 3,5 & 2,3 & 3,8 & 2,7 \\
\hline 5 & Палюстровая & 1,9 & 5,5 & 5,8 & 7,3 & 5,8 & 10,6 & 3,3 \\
\hline
\end{tabular}


Заключение. Методом ${ }^{1} \mathrm{H}$ и ${ }^{13} \mathrm{C}$ ЯМР изучены термические реакции двух образцов канифоли и выделенной из нее абиетиновой кислоты при температурах 190 и $220^{\circ} \mathrm{C}$ в открытых керамических тиглях с доступом воздуха. Было установлено, что термические реакции при указанных температурах протекают по-разному. Нагревание при более низкой температуре приводит к изомеризации СК абиетанового скелета с установлением нового их содержания из-за обменных реакций. Роль кислорода в этих условиях так же, как и деструкция кислот, незначительна. Концентрация абиетиновой кислоты сначала возрастает, а затем выходит на плато.

При нагревании смеси, обогащенной абиетиновой кислотой, последняя заметно расходуется с образованием остальных присутствующих в смеси кислот.

Повышение температуры до $220^{\circ} \mathrm{C}$ приводит к заметной деструкции СК канифоли и их эффективному взаимодействию с молекулярным кислородом с образованием новых кислот и кетонов.

\section{Список литературы}

1. Manar El-Sayed Abdel-Raouf, Abdul-Raheim Mahmoud Abdul-Raheim. Rosin: chemistry, derivatives and applications // BAOJ Chem. 2018. Vol. 4, no. 1. P. 1-16.

2. Термическая изомеризация левопимаровой кислоты, изученная методом ЯМР / Е. Д. Скаковский [и др.] // Структура и динамика молекулярных систем: сб. ст. XIV Bсерос. конф. Яльчик, 2007. C. $545-548$.

3. Stinson J. S., Lawrence Ray V. Thermal isomerization of gum rosin // Ind. Eng. Chem. 1954. Vol. 46, no. 4. P. 784-787.

4. Соколов А. Г. Химические превращения смоляных кислот при термической обработке живицы и канифоли: автореф. дис. ... канд. хим. наук / Институт лесохозяйственных проблем и химии древесины АН ЛатвийскойССР. Рига, 1962. 20 с.

5. Бардышев И. И., Соколов А. Г., Ткаченко О. Т. Тепловая изомеризация канифоли // Журнал прикладной химии. 1959. № 13. С. 2560-2566.

6. Соколов А. Г. К вопросу термической изомеризации некоторых смоляных кислот живицы сосны обыкновенной // Сборник трудов ЦНИЛХИ. 1959. № 13. С. 119-127.

7. Полежаева Н. И., Тарасова Л. С. Термическая деструкция канифоли // Химия и химическая технология. 2008. Т. 51, № 11. С. 37-40.

8. ЯМР-анализ состава канифолей / А. Ю. Клюев [и др.] // Структура и динамика молекулярных систем: сб. ст. XVI Всерос. конф. Йошкар-Ола, 2009. Вып. XVI. С. 216-219.

9. Применение спектроскопии ЯМР для анализа состава эфирного масла хвои сосны / Е. Д. Скаковский [и др.] // Журнал прикладной спектроскопии. 2006. Т. 73, № 2. С. 246-249.

10. Комшилов Н. Ф. Состав кислотной части живицы и канифоли // Канифоль, ее состав и строение смоляных кислот. 1965. Гл. 3. С. 54-71.

11. Isolation of apoptosis- and differentiation-inducing substances toward human promyelocytic leukemia HL-60 cells from of juniperus taxifolia / N. Muto [et al.] // Bioosci. Biotechnol. Biochem. 2008. Vol. 72, no. 2. P. 477-484.

\section{References}

1. Manar El-Sayed Abdel-Raouf, Abdul-Raheim Mahmoud Abdul-Raheim. Rosin: chemistry, derivatives and applications. BAOJ Chem., 2018, vol. 4, no. 1, pp. 1-16.

2. Skakovskii E. D., Tychinskaya L. Yu., Gaidukevich O. A., Klyuev A. Yu., Kozlov N. G., Baranovsky A. V., Rykov S. V. Thermal isomerization of levopimaric acid, studied by NMR. Sbornik statey XIV Vserossiyskoy konferentsii "Struktura i dinamika molekulyarnykh system" [Digest of articles of the XIV All-Russian Conference "Structure and Dynamics of Molecular Systems"]. Yalchik, 2007, pp. 545-548 (In Russian).

3. Stinson J. S., Lawrence Ray V. Thermal isomerization of gum rosin. Ind. Eng. Chem., 1954, vol. 46, no. 4, pp. 784-787.

4. Sokolov A. G. Khimicheskiye prevrashcheniya smolyanykh kislot pri termicheskoy obrabotke zhivitsy $i$ kanifoli. Avtoref. dis. kand. khim. nauk [Chemical transformations of resin acids during heat treatment of resin and rosin. Abstract of thesis cand. of chem. sci.]. Riga, 1962. 20 p.

5. Bardyshev I. I., Sokolov A. G., Tkachenko O. T. Thermal isomerization of rosin. Zhurnal prikladnoy khimii [Journal of Applied Chemistry], 1959, no. 13, pp. 2560-2566 (In Russian).

6. Sokolov A. G. On the issue of thermal isomerization of some resin acids of Scots pine resin. Sbornik trudov TSNILKHI [Proceedings of the Central Scientific Research Institute of Agriculture], 1959, no. 13, pp. 119-127 (In Russian).

7. Polezhayeva N. I., Tarasova L. S. Thermal destruction of rosin. Khimiya i khimicheskaya tekhnologiya [Chemistry and Chemical Technology], 2008, vol. 51, no. 11, pp. 37-40 (In Russian). 
8. Klyuev A. Y., Skakovskii E. D., Tychinskaya L. Yu., Gaidukevich O. A., Kozlov N. G., Lamotkin S. A., Rykov S. V. NMR analysis of rosin composition. Sbornik statey XIV Vserossiyskoy konferentsii "Struktura $i$ dinamika molekulyarnykh system" [Digest of articles of the XVI All-Russian Conference "Structure and Dynamics of Molecular Systems"'. Yoshkar-Ola, 2009, issue XVI, pp. 216-219 (In Russian).

9. Skakovskii E. D., Lamotkin S. A., Shpak S. I., Tychinskaya L. Yu., Gaidukevich O. A., Lamotkin A. I. Application of NMR spectroscopy for the analysis of the composition of pine needles essential oil. Zhurnal prikladnoy spektroskopii 「Journal of Applied Spectroscopy], 2006, vol. 73, no. 2, pp. 246-249 (In Russian).

10. Komshilov N. F. The composition of the acidic part of the resin and rosin. Kanifol', yeye sostav $i$ stroyeniye smolyanykh kislot [Rosin, its composition and structure of resin acids], 1965, ch. 3, pp. 54-71 (In Russian).

11. Muto N., Tomokuni T., Haramoto M., Tatemoto H., Nakanishi T., Inatomi Yu., Murata H., Inada A. Isolation of apoptosis- and differentiation-inducing substances toward human promyelocytic leukemia HL-60 cells from of juniperus taxifolia. Bioosci. Biotechnol. Biochem., 2008, vol. 72, no. 2, pp. 477-484.

\section{Информация об авторах}

Скаковский Евгений Доминикович - кандидат химических наук, ведущий научный сотрудник лаборатории физико-химических методов исследования. Институт физико-органической химии Национальной академии наук Беларуси (220072, г. Минск, ул. Сурганова, 13, Республика Беларусь). E-mail: sed@ifoch.bas-net.by

Тычинская Людмила Юльевна - кандидат химических наук, заведующий лабораторией физико-химических методов исследования. Институт физико-органической химии Национальной академии наук Беларуси (220072, г. Минск, ул. Сурганова, 13, Республика Беларусь). E-mail: spektr@ifoch.bas-net.by

Матвейчук Сергей Васильевич - кандидат химических наук, ведущий научный сотрудник лаборатории физико-химических методов исследования. Институт физико-органической химии Национальной академии наук Беларуси (220072, г. Минск, ул. Сурганова, 13, Республика Беларусь). E-mail: msv@ifoch.bas-net.by

Клюев Андрей Юрьевич - доктор технических наук, профессор кафедры технологии деревообрабатывающих производств. Белорусский государственный технологический университет (220006, г. Минск, ул. Свердлова, 13а, Республика Беларусь). E-mail: andrey_kluev_bstu@mail.ru

Гапанькова Елена Игоревна - младший научный сотрудник тематической группы химии азотсодержащих органических веществ. Институт физико-органической химии Национальной академии наук Беларуси (220072, г. Минск, ул. Сурганова, 13, Республика Беларусь). E-mail: elenagapankova@gmail.com

Латышевич Ирина Александровна - научный сотрудник тематической группы химии азотсодержащих органических веществ. Институт физико-органической химии Национальной академии наук Беларуси (220072, г. Минск, ул. Сурганова, 13, Республика Беларусь). E-mail: irinalatyshevitch@gmail.com

\section{Information about the authors}

Skakovskii Evgeniy Dominikovich - PhD (Chemistry), Leading Researcher of the Laboratory of Physical-Chemical Methods of Research. Institute of Physical and Organic Chemistry of the National Academy of Sciences of Belarus (13, Surganova str., 220072, Minsk, Republic of Belarus). E-mail: sed@ifoch.bas-net.by

Tychinskaya Lyudmila Yul'evna - PhD (Chemistry), Head of the Laboratory of Physical-Chemical Methods of Research. Institute of Physical and Organic Chemistry of the National Academy of Sciences of Belarus (13, Surganova str., 220072, Minsk, Republic of Belarus). E-mail: spektr@ifoch.bas-net.by

Matveichuk Sergei Vasilievich - PhD (Chemistry), Leading Researcher of the Laboratory of PhysicalChemical Methods of Research. Institute of Physical and Organic Chemistry of the National Academy of Sciences of Belarus (13, Surganova str., 220072, Minsk, Republic of Belarus). E-mail: msv@ifoch.bas-net.by

Klyuev Andrey Yur'yevich - DSc (Engineering), Professor of the Department of Woodworking Technology. Belarusian State Technological University (13a, Sverdlova str., 220006, Minsk, Republic of Belarus).E-mail: andrey_kluev_bstu@mail.ru

Hapankova Alena Igorevna - Junior Researcher of a Theme Group of Chemistry of Nitrogen-Containing Organic Substances. Institute of Physical and Organic Chemistry of the National Academy of Sciences of Belarus (13, Surganova str., 220072, Minsk, Republic of Belarus). E-mail: elenagapankova@gmail.com

Latyshevich Iryna Aleksandrovna - researcher of a Theme Group of Chemistry of Nitrogen-Containing Organic Substances. Institute of Physical and Organic Chemistry of the National Academy of Sciences of Belarus (13, Surganova str., 220072, Minsk, Republic of Belarus). E-mail: irinalatyshevitch@gmail.com 